Orginal article

\title{
Probability of obstructive sleep apnea in male patients with systolic heart failure and some related factors
}

\author{
Sharareh Zeighami Mohammadi ${ }^{1}$, Mandana Shahparian ${ }^{2}$, Habib Allah Esmaeili $^{3}$
}

(Received: 13 Sep 2014; Accepted: 15 Oct 2014)

\begin{abstract}
Background and Purpose: Sleep breathing disorders have a negative impact on the illness outcome and quality of life in patients with heart failure. This study was conducted to investigate the probability of obstructive sleep apnea in men with heart failure and some related factors.

Method: This was a cross-sectional study conducted on 100 male patients with systolic heart failure selected through convenience sampling. Demographic data, anthropometric indices, and information about the disease, treatment, and STOPBANG questionnaires were collected through interviewing subjects. Data was analyzed with SPSS 18 using descriptive statistics, t-test, Pearson correlation and linear regression.

Results: $87 \%$ of heart failure patients were at a high risk of obstructive sleep apnea. The probability of obstructive sleep apnea had significant relationship with age and neck circumference $(\mathrm{p}<0.001)$. A significant difference was found in the mean score of obstructive sleep apnea compared with renal disease $(\mathrm{p}=0.020)$, use of angiotensin receptor blockers $(\mathrm{p}=0$. 013$)$ and diuretics ( $\mathrm{p}=0.019)$.

Conclusion: Due to their longer and more direct contact with patients, nurses have more opportunity for evaluating obstructive sleep apnea in patients. Obstructive screening questionnaires of sleep breathing disorders is a simple and economical way for identifying the patients with a high risk of this problem and referring them for more accurate diagnosis and treatment, which can play an important role in reducing the negative outcomes of the disease and improving patients' quality of life.
\end{abstract}

Keywords: Obstructive sleep apnea, Heart failure, Men

\section{Introduction}

Heart failure is a clinical syndrome which is the outcome of disorder in heart structure or its performance (1). Heart failure incidence in Iran is reported to be 3500 patients out of 100000 people, which seems to be increasing due to the change in the age pyramid of the society and today young population getting older in near future (2). Annually, over 39 billion dollars are spent on looking after these patients in America (3). Despite recent developments in treating this disease, its outcome is still weak, and improving these patients' quality of life is one of the most important challenges of the health care system, their primary treatment, and looking after them (4).

Sleep quality and quantity do have an impact on health and they are always thought of as effective factors for heart failure patients' quality of life (5). Chen et al. (2009) reported that 74 percent of heart failure patients suffer from sleep disorders in various ways (6). The incidence of the Sleep

\footnotetext{
${ }^{1}$ Corresponding author: Department of Nursing, College of Nursing and Midwifery, Karaj Branch, Islamic Azad University, Alborz, Iran/ Email: zeighami@kiau.ac.ir.

${ }^{2}$ Cardiologist, Social Security Alborz Hospital, Karaj, Iran.

${ }^{3}$ Department of Public Health Epidemiology, School of Medicine, Mashhad University of Medical Sciences, Mashhad, Iran.
} 
Breathing Disorder is one of the common types of sleep disorders in these patients. The heart failure patients is estimated to range 56-88 percent Sleep Apnea (OSA) and Central Apnea (12). OSA results from nasopharyngeal muscle relaxation and upper airway collapse (13). This disorder leads to severe snoring, hypoventilation, stop in breathing, and frequent waking of the patient (14). The consequence of which is daily drowsiness, fatigue, disorder in daily performance, disorder in concentration, irritability, cognitive impairment and mood disorders (14-16). During sleep breathing interruptions, hypoxia causes autonomic system stimulation and hemodynamic, hormonal, neurological, and cardiovascular changes (17). Some negative effects of OSA in patients with heart failure are decrease in disease prognosis (12), exacerbation of symptoms and severity of disease (18), increased severity of the left ventricular dysfunction (19), arrhythmias (20), increased rate of readmission (21), need to use more health care services (22), and increased morbidity and mortality (15). Evidence show that diagnosing and treating OSA is effective in improving left ventricular ejection fraction $(11,12)$, decrease in daily drowsiness, improving mood, cognitive performance (23-25), and life quality of the patients with heart failure (26).

Various factors have role in OSA emeregence such as ageing, masculineness, severity of heart failure and ventricular ejection fraction, anatomic disorder and tendency for collapsibility of the upper airway, throat area edema, congestion of neck veins and external pressure on airway due to fat accumulation around neck $(2,3)$.

Different studies in Iran have focused on sleep quality, daily drowsiness, and sleep disorder spectrum in patients with heart failure $(27,5)$, but OSA in patients with heart failure and its related factors have rarely been taken into account.

Despite high incidence and negative consequences of OSA, its diagnosis and treatment is not accounted as a routine part of evaluation and treatment of the patients with heart failure (28). According to the negative impacts of OSA on life quality and its negative consequences for patients with heart failure and also more incidence of this disorder in male patients, this study aims to investigate the probability of OSA in males with heart failure and some of its related factors.

\section{Materials and Methods}

The present study is a descriptive cross-sectional one the subjects of which are all of the patients with heart failure hospitalized in the interior unit of Alborz Social Security Hospital of Karaj and Shahriyar Social Security Hospital from June to December in 2010. This study was a part of a broader correlated one; using the rate of correlation between the understudy variables with reliability of 99 and the strength of 90 percent, and also using this formula: $\mathrm{N}=((2.58+1.64) / \mathrm{c})^{2}+3$, it has been calculated for the sample size of 21 patients. But for the probability and controlling interfering variables and more precision, the sample size was increased to 100 subjects.

According to the criteria of the study (masculineness, having been suffering at least one year from heart failure, equal and less than $40 \%$ ejection fraction), 100 patients suffering from systolic heart failure were selected via the convenient sampling. Data was gathered through interviewing patients. Left ventricular ejection fraction was deduced based on the echocardiography results already existing in the patients' records. Information about anthropometric indices (measuring height, weight, neck circumference, waist circumference) was obtained using a plastic tape measure and bascule of the unit. The neck circumference was measured at the mid part of the neck height where thyroid cartilage is, and waist circumference was measured at the narrowest part in the upper part of the body between ribs and iliac spines of the pelvis. Body mass index (BMI) was obtained by dividing weight in kilogram 
by height in meter square. According to American Heart Association, BMI is defined in three categories: less that 24.9 kilograms per square meter (normal), between 25 and 29.9 (overweight), and more than 30 (obesity). Waist circumference more than 0.9 centimeters (29) and neck circumference more than 40 centimeters in men is defined as central obesity (31).

STOP-BANG questionnaire including 8 yes/no questions about masculineness, case history of frequent snoring with a loud noise, drowsiness during the day, breathing stops while sleeping, case history of hypertension, age over 50, BMI over 35 kilograms per square meter $\left(\mathrm{kg} / \mathrm{m}^{2}\right)$, and neck circumference over 40 centimeters which would screen the probability of OSA. Measuring height and weight and neck circumference were done by the researcher and the rest was done through interviewing. The scores ranged from 0 to 8 ; scores of 1 to 2 would show low probability, and 3 to 8 means high probability for OSA. Compared with apnea hypo index, this tool has an appropriate

cut-off point for screening and is highly sensitive (83.6 to $100 \%$ ) for identifying susceptible people to OSA (30-31). Comparing the four-variable screening tool, STOP, STOP-Bang, and Epworth Sleepiness Scales, this tool is introduced to clinical specialists as the best method for screening OSA (30). The validity of the tool in the Chung's study in 2008 was reported to be 0.96 in re-test (31). In the current study, to determine the reliability coefficient of STOP-BANG questionnaire, test-retest was used. For this purpose, the questionnaires were given to 10 patients with heart failure in two stages with an interval of 10 days and the correlation of 0.90 was obtained between the tests of the two stages. Ethical considerations were taken into account by getting permission from the medical research ethical committee of Islamic Azad University of Karaj, gaining permission from the authorities of hospital for conducting the study, explaining the goals and research method for every subject, and getting written consent from them. Data was analyzed by SPSS 18 and described with tables of frequency distribution, mean and standard deviation; they were analyzed with t-test, Pearson correlation coefficient and linear regression via Enter method. Significance level in this study was considered to be 0.05 .

\section{Results}

The mean age of men suffering from systolic heart failure was $59.2 \pm 11.9$, ranging from 34 to 88 years old, and average length of $4.5 \pm 2.9$ years suffering from heart failure, ranging from 1 to 15 years. 42 percent of them had primary education, 51 percent were retired, and 62 percent were non smokers. The mean of left ventricular ejection fraction was $35.1 \pm 7.4$ ranging from 10 to 40 percent. The most accompanied diseases were hypertension (33\%) and diabetes (33\%). $41 \%$ of subjects were treated with digoxin, 38\% with diuretics, 29\% with angiotensin-converting enzyme, $5 \%$ with calcium blockers, $19 \%$ with beta-blockers, $74 \%$ with nitrate, $35 \%$ with angiotensin receptor blockers and $8 \%$ with spironolactone.

Information about the mean neck circumference, waist circumference, BMI, and the score of STOPBANG questionnaire are given in Table 1.

Table 1: Mean of neck circumference, Waist circumference, BMI, and OSA in men with systolic heart failure

\begin{tabular}{lccc}
\hline Variable & $\begin{array}{c}\text { Std.Deviation } \\
\pm \text { Mean }\end{array}$ & Maximum & Minimum \\
\hline Neck Circumference $(\mathrm{cm})$ & $40.4 \pm 2.8$ & 47.0 & 33.0 \\
Waist circumference $(\mathrm{cm})$ & $94.3 \pm 14.3$ & 135.0 & 50.0 \\
BMI $\left(\mathrm{kg} / \mathrm{m}^{2}\right)$ & $26.1 \pm 4.4$ & 48.4 & 18.5 \\
OSA & $4.2 \pm 1.4$ & 7.0 & 1.0 \\
\hline
\end{tabular}

The obtained results suggested that 51 percent of men affected by systolic heart failure had a neck circumference over 40 centimeters, 22 percent had a 
waist circumference over 102 centimeters; based on BMI, 51 percent were overweight, and 10 percent were fat. According to the raised indices in the STOP BANG questionnaire, 79 percent of the subjects were over 50,33 percent were undertreatment of hypertension, 51 percent had a neck circumference over 40 centimeters, 4 percent had BMI over 35 kilograms per square meter, 48 percent had daily drowsiness, 61 percent snoring during sleep, and 48 percent had apnea. Based on the cut-off point, 13 percent were at a low risk, and 87 percent were at high risk of OSA.

The results of Pearson Correlation Coefficient, the significant positive correlation between OSA and age $(p=0.002, \quad r=0.284)$, neck circumference $(\mathrm{p}<0.001, \mathrm{r}=0.462)$, waist circumference $(\mathrm{p}=0.004$, $\mathrm{r}=0.284)$, BMI $\quad(\mathrm{p}=0.009, \mathrm{p}=0.259)$, and the significant inverse correlation with left ventricular ejection fraction $(\mathrm{p}<0.013, \mathrm{r}=-0.247)$ revealed that after doing linear regression, the final pattern indicates that only age and neck circumference had significant relationship with OSA $(\mathrm{p}<0.001)$ so that age and neck circumference would explain 40.7 percent of OSA variance (Table 2).

Table 2. linear regression test via Enter method for factors related to OSA in men affected by systolic heart failure.

\begin{tabular}{lcccccc}
\hline Model & $\begin{array}{c}\text { Beta } \\
\text { standa } \\
\text { rdaized }\end{array}$ & $\begin{array}{c}\text { Std. } \\
\text { Error }\end{array}$ & t-value & Sig. & \multicolumn{2}{c}{$\begin{array}{c}\text { 95\% Confidence } \\
\text { Interval for B }\end{array}$} \\
\hline constant & 0.398 & 0.010 & 4.610 & $<0.001$ & .0069 & 0.027 \\
$\begin{array}{l}\text { Age } \\
\text { LVEF } \\
\text { (Left ventriaular } \\
\text { ejection fraction) }\end{array}$ & -0.090 & 0.017 & -1.020 & 0.310 & 0.016 & -0.050 \\
$\begin{array}{l}\text { Neck } \\
\text { circumference } \\
\text { Waist } \\
\text { circumference }\end{array}$ & 0.420 & 0.047 & 4.474 & $<0.001$ & 0.302 & 0.116 \\
BMI & 0.153 & 0.009 & 1.586 & 0.116 & 0.034 & -0.004 \\
\hline R square $=0.407$ & 0.105 & 0.034 & 0.969 & 0.335 & 0.101 & -0.035 \\
\hline
\end{tabular}

The mean difference of STOP-BANG questionnairescores, based on suffering from some chronic diseases, smoking, and the drugs type taken are given in Table 3.
Table 3. comparing the scores of STOP-BANG questionnaire, based on suffering from some chronic diseases, smoking, and the type of drugs taken in men suffering from systolic heart failure.

\begin{tabular}{|c|c|c|c|}
\hline Variable & Yes & No & $\begin{array}{c}\text { Result of } \\
\text { t-test }\end{array}$ \\
\hline & $\begin{array}{c}\text { Std.Deviation } \\
\pm \text { Mean }\end{array}$ & $\begin{array}{c}\text { Std.Deviation } \\
\pm \text { Mean }\end{array}$ & \\
\hline Suffering from hypertension & & $4 \pm 1.4$ & $\begin{array}{l}\mathrm{t}=1.847 \\
\mathrm{p}=0.068\end{array}$ \\
\hline Suffering from diabetes & $4.1 \pm 1.4$ & $4.2 \pm 1.4$ & $\begin{array}{l}t=-0.289 \\
p=0.773\end{array}$ \\
\hline $\begin{array}{l}\text { Suffering from kidney } \\
\text { disease }\end{array}$ & $5.4 \pm 1.2$ & $4.1 \pm 1.3$ & $\begin{aligned} \mathrm{t} & =2.369 \\
\mathrm{p} & =0.020^{*}\end{aligned}$ \\
\hline $\begin{array}{l}\text { Chronic obstructive } \\
\text { pulmonary disease }\end{array}$ & $4.2 \pm 1$ & $4.2 \pm 1.4$ & $\begin{array}{l}\mathrm{t}=0.081 \\
\mathrm{p}=0.936\end{array}$ \\
\hline Ischemic heart disease & $4.2 \pm 1.6$ & $4.2 \pm 1.3$ & $\begin{array}{l}t=-0.129 \\
p=0.900\end{array}$ \\
\hline Smoking & $4 \pm 1.4$ & $4.3 \pm 1.3$ & $\begin{array}{r}\mathrm{t}=-1.340 \\
\mathrm{p}=0.183\end{array}$ \\
\hline Digoxin use & $4.2 \pm 1.4$ & $4.2 \pm 1.4$ & $\begin{array}{l}t=0.121 \\
p=0.904\end{array}$ \\
\hline $\begin{array}{l}\text { Use of Angiotensin } \\
\text { converting enzyme } \\
\text { inhibitors }\end{array}$ & $9.8 \pm 1.3$ & $4.3 \pm 1.3$ & $\begin{array}{c}\mathrm{t}=-1.571 \\
\mathrm{p}=0.120\end{array}$ \\
\hline Spironolactone use & $5.1 \pm 0.6$ & $4.1 \pm 1.4$ & $\begin{array}{l}t=1.877 \\
p=0.063\end{array}$ \\
\hline Diuretic use & $4.6 \pm 1.2$ & $3.9 \pm 1.4$ & $\begin{array}{c}\mathrm{t}=0.603 \\
\mathrm{p}=0.019^{*}\end{array}$ \\
\hline $\begin{array}{l}\text { Angiotensin receptor } \\
\text { blockers }\end{array}$ & $4.7 \pm 1.1$ & $3.9 \pm 1.4$ & $\begin{array}{r}\mathrm{t}=2.539 \\
\mathrm{p}=0.013^{*}\end{array}$ \\
\hline Nitrate & $4.1 \pm 1.4$ & $4.3 \pm 1.2$ & $\begin{array}{r}\mathrm{t}=-0.607 \\
\mathrm{p}=0.545\end{array}$ \\
\hline Estatines & $3.9 \pm 1.4$ & $4.3 \pm 1.3$ & $\begin{array}{c}\mathrm{t}=-1.363 \\
\mathrm{p}=0.176\end{array}$ \\
\hline Beta blocker & $4.3 \pm 1.6$ & $4.2 \pm 1.3$ & $\begin{array}{l}t=0.259 \\
p=0.796\end{array}$ \\
\hline Calcium blocker & $4.2 \pm 1.3$ & $4.2 \pm 1.9$ & $\begin{array}{l}\mathrm{t}=-0.065 \\
\mathrm{p}=0.948\end{array}$ \\
\hline
\end{tabular}

\section{Discussion}

In the present study, 87 percent of men suffering from systolic heart failure were at the risk of OSA. This finding is in line with Isakson 's study results in 2008 implying that 83 percent of the patients with heart failure, 98 percent of which were male were suffering from OSA (10). In Paulino's study in 2009, also 70 percent of the patients with heart failure, 83 percent of which were male suffered from OSA (7). Common symptoms of heart failure and apnea makes the diagnosis of OSA in patients with heart failure difficult. For instance, fatigue, daily drowsiness, decrease in physical activity and cognitive disorder can be the outcome of heart failure or OSA (32). Probably one of the reasons is related to conducting the study for male patients. 
Because evidence show that the prevalence of OSA in males is more than that in females $(8,9,33)$. It seems that the comparison of the probability of being affected by OSA, through questionnaires designed for screening with reported accurate values in papers determined with polysomno graphy despite high sensitivity, must be done with caution. Then, according to its being economical and having high sensitivity, this tool is recommended to be used after two steps: first following up the subjects by screening questionnaire; and second by polysomnography.

In the present study, the older men suffering from systolic heart failure were more at the risk of OSA. In Javadi's study, the mean age of the patients with OSA $(63 / 8 \pm 9 / 3)$ was more than that of the patients without OSA (61/4 $\pm 10 / 6)$ (34). In Sin's study in 1999, age over 60 was one of the important factors for the risk of apnea in the patients with heart failure (15). However, this finding was not in line with the finding of Mirzaaghazadeh et al. in 2014 and that of Ferreira et al. in 2010, stating that there is no relationship between OSA and age $(9,11)$. Probably the difference between the findings can be due to the kind of study, the age of the subjects, selecting only males, and suffering from a systolic kind of heart failure in the current study and the difference in OSA evaluation method. Change and increase in the probability of OSA was observed in older patients more than in the younger ones (35). Probably poor function of muscles of holding the airway open has a role in increasing apnea in the aged people.

In the present study, the men suffering from systolic heart failure who had a higher neck circumference were more probable to be affected by OSA. This finding was consistent with the result of the study by Ferreira et al. in 2010 displaying that there is a relationship between OSA and neck circumference (9). OSA occurs when there is lack of balance between the powers of confining and those of opening the airway. Increase in the negative pressure in the airway by the diaphragm and the pressure from outside of the airway by supporting tissue of airway causes its collapsibility increase (32). It seems that two factors have a role in increasing the neck circumference and raising the probability of being affected by OSA. One is accumulation and distribution of fat in the neck area and Parapharyngeal (36). It is always notified that besides the rate of fatty tissue in the body, the quality of its distribution is very important, too (26). Distribution of fatty tissue in thorax, abdomen, and proximal parts of the upper body is known as central obesity (23). Measuring neck circumference is one of the simplest, newest and the most valid screening methods of central obesity which shows fat distribution in the upper part of the body (37). The second effective factor in increasing neck circumference is edema in the throat area and congestion of neck veins which increases the airway capability of being obstructed (29). In the present study, the measure of edema around the neck and throat area was not evaluated, and this can be considered as a limitation. Increase in neck circumference, either due to edema caused by uncompensated heart failure or accumulation of fatty tissue, can increase the probability of OSA in the patients with heart failure.

In the current study, the male patients with heart failure, who had renal dysfunction too, were at a higher risk of OSA. It seems that this relationship can be due to some different factors; first, in the patients with OSA, relative or complete obstruction of the airway during sleep increases due to the respiratory effort of the negative intra thoracic pressure, and this causes an increase in returning the venous blood to the heart and increase in preload in the right ventricle. Increase in right ventricular preload causes a shift of the inter ventricular wall toward the left side during diastole, which leads to the reduction in the left ventricular preload. Decrease in ventricle preload leads to decrease in stroke volume and in cardiac 
output during apnea attacks (18). Reduction in left ventricular ejection fraction gradually deranges the function of the kidneys because of reduction of vascularization to them, and this matter causes decreasing response to diuretic, the resistance against diuretic, and increase in liquid load of the body, which causes heart dysfunction and intensifies its failure and weakness. The interplay between the functions of heart and kidney is called cardiorenal syndrome $(38,39)$. Moreover, disorders in the function of the heart and kidneys cause the suppression of liquids in the body enforcing the chance of respiratory problems during sleep with liquid translocation and spread to the upper part of the body $(29,32,40)$. Second , during simpatico stimulation OSA, increase in aldosterone angiotensin renin leads to hypertension, which is one of the major factors of renal dysfunction (41). So, it seems that there can be a mutual relationship between the functions of heart, kidney and OSA. In the present study, the patients under the treatment with diuretics and angiotensin receptor blockers are more at the risk of OSA. The results of Cicolin's study in 2006 showed that using angiotensin-converting enzyme inhibitors intensifies sleep disorders (42). In Tanabe's study in 2011, one of predictive factors of sleep disorders in the patients with hypertension is taking angiotensin converting enzyme inhibitors (43). But this finding was not in line with Sin's results in 1999 indicating that there is no relationship between taking diuretic and angiotensin converting enzyme inhibitors and respiratory disorders in the patients with heart failure (15). The results of Bucca's study in 2007were also contradictory to those of the present study revealing that using foresmaid and spironolactone for three days in the patients with heart failure leads to increase in the airway diameter and reduction in the index of hypopnea in polysomnography examination (44). Probably stimulating simpatico, the activity of aldosterone angiotensin renin system, and consequently, increased hypertension, liquid suppression in the body, and intensifying edema increases the need for medical treatment of reducing blood pressure and edema. Of course, according to the contradictory findings, more study and investigation is recommended on the effects of taking drugs on sleep respiratory disorders.

The men suffering from systolic heart failure with central obesity, at a higher age, with renal dysfunction, and under the treatment taking antihypertension drugs were at a high risk of being afflicted by OSA. Disorder in sleep schedule is a nursing diagnosis; because of their direct and longer contact with patients, nurses have more opportunity for evaluating apnea in patients.Screening questionnaires of apnea are a convenient and economical way to identify the patients with high risk, and refer them for more accurate diagnosis and treatment, which can have an important role in decreasing negative outcomes of the disease and improving the patients' life quality. Not using the exact method of polysomnography for verifying OSA, and sampling, which is not accidental and is based on the patients' data in two hospitals, decreases the obtained results generalizing potential. So, it is recommended that other studies be conducted on two genders with performing polysomnography and observing the criteria for generalizing the results.

\section{Conflict of interest}

The author declares his lack of conflict with interest through his article.

\section{Author's contributions}

SH. Zeighami cooperated in planning, conducting, statistical analysis, and developing the article \& Dr.Shahparian participated in planning and gathering data, and Dr. Esmaeili helped in calculating sample size and advising for data analysis. 


\section{Acknowledgments}

The present study has been a part of the result of the proposal with this code: $1 / 11972$. Thereby, the vice-chancellor of the Islamic Azad University of Karaj is appreciated for approving and financial support of the research proposal.

\section{References}

1. Guha K, McDonagh T. Heart failure epidemiology: European perspective. Curr Cardiol Rev. 2013; 9(2): 123-127. PMID: 23597298.

2. Bagheri H, Yaghmaei F, Ashtorabi T, Zayeri F. Psychometric properties of Illness Related Worries Questionnaire (IRWQ) in heart failure patients. Iran J Psy Nurs. 2014; 2(1): 23-33 (persian).

3. Roger VL. Epidemiology of heart failure. Circ Res. 2013; 113(6): 646-659. PMID: 23989710.

4. Zeighami Mohammadi SH, Shahparian M. Quality of Life (Qol) and some factors related in males with heart failure in Karaj and Shahriar social security hospitals (2010). JGBFNM. 2012; 8(2): 1-13 (persian).

5. Zeighami Mohammadi SH, Shahparian M. Evaluation of sleep problems and its associated factors in male patients with systolic heart failure. Qom Univ. Med Sci J. 2013; 6(4): 64-73 (persian).

6. Chen HM, Clark AP, Tsai LM, Chao YF. Selfreported sleep disturbance of patients with heart failure in Taiwan. Nurs Res. 2009; 58(1): 63-71. PMID: 19092556.

7. Paulino A, Damy T, Margarit L, Stoica M, Deswarte G, Khouri L, et al. Prevalence of sleep-disordered breathing in a 316-patient French cohort of stable congestive heart failure. Arch Cardiovasc Dis. 2009; 102(3): 169-175. PMID: 19375670.

8. Silva RS, Figueiredo AC, Mady C, Lorenzi-Filho G. Breathing disorders in congestive heart failure: gender, etiology and mortality. Braz J Med Biol Res. 2008; 41(3): 215-222. PMID:18575711.

9. Ferreira S, Marinho A, Patacho M, Santa-Clara E, Carrondo C, Winck $\mathrm{J}$, et al. Prevalence and characteristics of sleep apnoea in patients with stable heart failure: Results from a heart failure clinic. BMC Pulm Med. 2010; 10: 9. PMID: 20199687.

10. Isakson SR, Beede J, Jiang K, Gardetto NJ, Gordon $\mathrm{N}$, Casal E, et al. Prevalence of sleep disordered breathing in congestive heart failure as determined by ApneaLink, a simplified screening device. Sleep Diag Therap. 2008; 3(7): 52-57.

11. Mirzaaghazadeh M, Bahtouee M, Mehdiniya F, Maleki N, Tavosi Z. The Relationship between nocturnal hypoxemia and left ventricular ejection fraction in congestive heart failure patients. Sleep Disord. 2014; 2014: 978358. PMID: 24693442.

12. Krawczyk M, Flinta I, Garncarek M, Jankowska EA, Banasiak W, Germany R, et al. Sleep disordered breathing in patients with heart failure. Cardiol J. 2013; 20(4): 345-355. PMID: 23913452.

13. Chowdhury M, Adams S, Whellan DJ. Sleepdisordered breathing and heart failure: focus on obstructive sleep apnea and treatment with continuous positive airway pressure. J Card Fail. 2010; 16(2): 164-174. PMID: 20142029.

14. Saddki N, Mohamad H, Mohd Yusof NI, Mohamad D, Mokhtar N, Wan Bakar WZ. Validity and reliability of the Malay version of sleep apnea quality of life index--preliminary results. Health Qual Life Outcomes. 2013; 11(1): 100. PMID: 23786866.

15. Sin DD, Fitzgerald F, Parker JD, Newton G, Floras JS, Bradley TD. Risk factors for central and obstructive sleep apnea in 450 men and women with congestive heart failure. Am J Respir Crit Care Med. 1999; 160(4): 1101-6. PMID: 10508793.

16. Schroder CM, Ohara R. Depression and Obstructive Sleep Apnea (OSA). Ann Gen Psychiatry. 2005; 4 : 13. PMID: 15982424.

17. Hersi AS. Obstructive sleep apnea and cardiac arrhythmias. Ann Thorac Med. 2010; 5(1): 10-17. PMID: 20351955.

18. Steiner S, Schueller PO, Hennersdorf MG, Strauer BE. Obstructive sleep apnea in heart failure patients: evidence for persistent conduction disturbances or sinus node dysfunction. J Physiol Pharmacol. 2008; 59 (Suppl 6): 669-674. PMID: 19218693.

19. Oldenburg O, Lamp B, Faber L, Teschler H, Horstkotte D, Töpfer V. Sleep-disordered breathing in patients with symptomatic heart failure: a contemporary study of prevalence in and characteristics of 700 patients. Eur J Heart Fail. 2007; 9(3): 251-257. PMID: 17027333.

20. Ferrier K, Campbell A, Yee B, Richards M, OMeeghan T, Weatherall M, et al. Sleep-disordered breathing occurs frequently in stable outpatients with congestive heart failure. Chest. 2005; 128(4): 2116-2122. PMID: 16236863. 
21. Khayat R, Abraham W, Patt B, Brinkman V, Wannemacher J, Porter K, et al. Central sleep apnea is a predictor of cardiac readmission in hospitalized patients with systolic heart failure. J Card Fail. 2012; 18(7): 534-340. PMID: 22748486.

22. Diaz K, Faverio P, Hospenthal A, Restrepo MI, Amuan ME, Pugh MJ. Obstructive sleep apnea is associated with higher healthcare utilization in elderly patients. Ann Thorac Med. 2014; 9(2): 92-98. PMID: 24791172.

23. Lau EY, Eskes GA, Morrison DL, Rajda M, Spurr KF. The role of daytime sleepiness in psychosocial outcomes after treatment for obstructive sleep apnea. Sleep Disord. 2013; 2013: 140725. PMID: 23766914.

24. Ejaz SM, Khawaja IS, Bhatia S, Hurwitz TD. Obstructive sleep apnea and depression: a review. Innov Clin Neurosci. 2011; 8(8): 17-25. PMID: 21922066.

25. El-Sherbini AM, Bediwy AS, El-Mitwalli A. Association between obstructive sleep apnea (OSA) and depression and the effect of continuous positive airway pressure (CPAP) treatment. Neuropsychiatr Dis Treat. 2011; 7: 715-721. PMID: 22247613.

26. Cormican LJ, Williams A. Sleep disordered breathing and its treatment in congestive heart failure. Heart. 2005; 91(10): 1265-70. PMID: 16162610.

27. Arasteh M. Evaluation of insomnia in medical students of Kurdestan University. Sci J Kurdistan Univ Med Sci. 2007; 12 (3 ): 58-63 (persian).

28. Khayat R, Small R, Rathman L, Krueger S, Gocke B, Clark L, et al. Sleep-disordered breathing in heart failure: identifying and treating an important but often unrecognized comorbidity in heart failure patients. J Card Fail. 2013; 19(6): 431-444. PMID: 23743494.

29. Lopez-Jimenez F, Cortes-Bergoderi M. Obesity and the heart. Rev Esp Cardiol (Engl Ed). 2011; 64(2):140-9. PMID: 24774873.

30. Silva GE, Vana KD, Goodwin JL, Sherrill DL, Quan SF. Identification of patients with sleep disordered breathing: comparing the four-variable screening tool, STOP, STOP-Bang, and Epworth Sleepiness Scales. J Clin Sleep Med. 2011; 7(5): 467-472. PMID: 22003341.

31. Chung F, Yegneswaran B, Liao P, Chung SA, Vairavanathan S, Islam S, et al. STOP questionnaire: a tool to screen patients for obstructive sleep apnea.
32. Anesthesiology. 2008; 108(5): 812-821. PMID: 25010615.

33. Valdivia-Arenas MA, Powers M, Khayat RN. Sleepdisordered breathing in patients with decompensated heart failure. Heart Fail Rev. 2009; 14(3): 183-193. PMID: 18758944.

34. Kasai T. Sleep apnea and heart failure. J Cardiol. 2012; 60(2): 78-85. PMID: 22824295.

35. Javadi HR, Jalilolghadr S, Yazdi Z, Rezaie Majd Z. Correlation between Obstructive Sleep Apnea Syndrome and Cardiac Disease Severity. Cardiovasc Psychiatry Neurol. 2014; 2014: 747293. PMID: 24701348.

36. Edwards BA, O’Driscoll DM, Ali A, Jordan AS, Trinder J, Malhotra A. Aging and sleep: physiology and pathophysiology. Semin Respir Crit Care Med. 2010; 31(5): 618-633. PMID: 20941662.

37. Schafer H, Pauleit D, Sudhop T, Gouni-Berthold I, Ewig S, Berthold HK. Body fat distribution, serum leptin, and cardiovascular risk factors in men with obstructive sleep apnea. Chest. 2002; 122(3): 829839. PMID: 12226021.

38. Nasrollah S, Jalalmanesh Sh, Mohammadzadeh Sh, Mahmoodi M. Relationship between higherstsndard neck circumference in women and risk factors of coronary artery disease. J Nurs Midwif. 2008; 18(60): 28-34 (Persian).

39. Bongartz LG, Cramer MJ, Doevendans PA, Joles JA, Braam B. The severe cardiorenal syndrome: Guyton revisited. Eur Heart J. 2005; 26(1): 11-17. PMID: 15615794.

40. Heywood JT. The cardiorenal syndrome: lessons from the ADHERE database and treatment options. Heart Fail Rev. 2004; 9(3): 195-201. PMID: 15809817.

41. Ozkok A, Kanbay A, Odabas AR, Covic A, Kanbay M. Obstructive sleep apnea syndrome and chronic kidney disease: a new cardiorenal risk factor. Clin Exp Hypertens. 2014; 36(4): 211-216. PMID: 24432915.

42. Adeseun GA, Rosas SE. The impact of obstructive sleep apnea on chronic kidney disease. Curr Hypertens Rep. 2010; 12(5): 378-383. PMID: 20676805.

43. Cicolin A, Mangiardi L, Mutani R, Bucca C. Angiotensin-converting enzyme inhibitors and obstructive sleep apnea. Mayo Clin Proc. 2006; 81(1): 53-55. PMID: 16438479.

44. Tanabe N, Fujita T, Fujii Y, Orii T. Investigation of 
the factors that contribute to the onset of insomnia in hypertensive patients by using a post-marketing surveillance database. Yakugaku Zasshi. 2011; 131(5): 669-677. PMID: 21532263.
45. Bucca CB, Brussino L, Battisti A, Mutani R, Rolla G, Mangiardi L, et al. Diuretics in obstructive sleep apnea with diastolic heart failure. Chest. 2007; 132(2): 440-446. PMID: 17699130. 